DOI: $10.2478 / \mathrm{v} 10122-010-0007-9$

\title{
NON-NOMINATIVE SUBJECTS IN RAJASTHANI AND CENTRAL PAHARI. THE STATUS OF THE ERGATIVE AND OBLIGATORY CONSTRUCTIONS ${ }^{1}$
}

\author{
KRZYSZTOF STROŃSKI
}

\begin{abstract}
Krzysztof Stroński. Non-Nominative Subjects in Rajasthani and Central Pahari. The Status of the Ergative and Obligatory Constructions. Lingua Posnaniensis, vol. LII (1)/2010. The Poznań Society for the Advancement of the Arts and Sciences. PL ISSN 0079-4740, ISBN 978-83-7654-030-6, pp. 81-97
\end{abstract}

It was noted very early (Kellog 1972 [1875]; Grierson 2005 [1916], vol. IX, part IV: 103-107) that Rajastahani and Pahari dialects displayed many morphological affinities. However languages belonging to both groups show different treatment of non-nominative subjects in ergative and obligatory constructions. Western Rajasthani is an example of constant drift towards nominativity and disappearance of the oblique subject marking in the ergative domain (cf. KнокнLоva 2001; 2006). Eastern Rajasthani reinforces the $\mathrm{A}$ and $\mathrm{O}$ contrast by introducing the $n e$ postposition which serves as a dative marker as well. Pahari dialects on the other hand consistently mark A of the transitive sentence with the le postposition which is also employed as an instrumental marker. Those dative and instrumental markers are also used in the obligatory constructions. Both types of markers are of recent origin but the ergative and obligatory patterns can be observed throughout the history of the IA languages. In Rajasthani and Pahari one can see two divergent morphological developments which have resulted in attrition and reinforcement of ergativity respectively. The situation seems to be more complex if we take into consideration specific developments in verbal agreement in Rajasthani and the maintenance of unmarked pronominal $\mathrm{O}$ in Kumauni (cf. SHARMA 1987) in ergative construction and the reinterpretation of the obligatory construction as future tense in Kumauni and Garhwali.

The present paper argues that despite the recent origin of case marking in IA languages they do share certain structural properties which are traceable historically. Introduction of new markers has served only to maintain structural pattern continuum. The employment of the ergative postposition with intransitive verbs (e.g. cough, laugh) (cf. MonTAUT 2004) and its implementation in the obligatory construction can be perceived as an attempt to rebuild the system which goes back neither to the ergative nor to accusative (cf. Klimov 1983; LeHMANn 1995; BaUer 2000).

Krzysztof Stroński, Institute of Linguistics, Adam Mickiewicz University, al. Niepodległości 4, PL - 61-874 Poznań

1 The present paper is a part of a research project which has been supported by Polish Ministry of Science and Higher Education grant N N104 215833. 


\section{INTRODUCTION}

It was noted very early (Kellog 1893 [1875]; Grierson 2005 [1916], vol. IX, part IV: 103-107) that Rajasthani and Pahari dialects (see map) displayed certain affinities at the morphological level in both the nominal and the verbal system. These convergences might have resulted from long-lasting contact between the languages. The dialects spoken on the plains by Rajputs had once ousted the speech of the Himalayan dwellers, i.e. Khaśas, who finally adopted the speech of the conquerors (GRIERSON 2005 [1916], vol. IX, part IV:108109). After centuries, however, we can see that despite morphological similarities which have been preserved in Rajasthani and Central Pahari, the outcome of the syntactic developments is considerably different.

In the present paper I would like to focus on two phenomena, namely on the ergative and obligatory constructions in both dialectal groups, which indicate an interesting evolution of what are generally assumed to be non-nominative subjects.

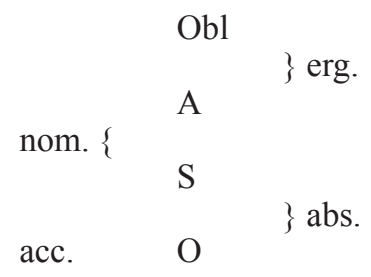

Fig. 1. Ergative alignment according to KLIMOV (1983: 112)

For the purpose of the present paper I will use the extended Dixonian (Dixon 1979; 1994) scheme proposed by KLIMOV (1983: 112-113) in which the same marking of A and $\mathrm{Obl}$ is perceived as one of the implications of ergativity (Figure 1).

\section{'ERGATIVE SUBJECTS' IN RAJASTHANI - LOSS OF ERGATIVE PATTERN}

Thanks to access to the oldest written records reaching back almost to the $14^{\text {th }}$ century $\mathrm{AD}$, the historical development of ergativity can be best reconstructed in Marwari. There have been a considerable number of synchronic descriptions of Rajasthani dialects written by vernacular (e.g. BAHL 1989; LĀLAS 1994) and Western authors (MAGIER 1983), but historical research occupies an important place, to mention only the earliest works by TESSITORI (1913; 1979 [1914-1916]) and some seminal papers by KнокнLоva (1974; 1992; 1995; $2000 ; 2001 ; 2002 ; 2006)$.

Old Marwari texts show clear evidence of the ergative alignment - in the perfective tenses, $\mathrm{S}$ and $\mathrm{O}$ (Nom. case) were grouped together and A (Instr.) was marked separately (see ex. (1) and (2)). Employment of the Instr. agent in the participial tenses based on the - $t a$ participle, inherited from the MIA period, conforms to the general tendencies observable in early NIA languages (KHокнLоvA 1992: 73-74). Unlike in the modern IA tongues, even animate or definite objects remain unmarked (3).

Such treatment of S, O and A is, however, not consistent - only pl. nouns and sg. stems ending in - $o$ had separate Instr. while the other nouns unified the Instr. and Nom. endings at a very early stage. Already in Old Rajasthani prose texts one can observe co-occurrence of Instr. and Nom. forms in the A function ((3) and (4)), which is obviously a sign of the 
disappearance of ergativity in Rajasthani (cf. TESSITORI 1979 [1914-1916]: 155; KHOKHLOvA 2006: 160-162):

$$
\text { isaum bhạ̣̄ kari haṃsu rājā ādhau cāliyau }
$$

like talk do.abs. H. king.Nom. far go.PPP.masc.sg.

Having said this king Hansu (S) went further. $15^{\text {th }}$ c AD (R.G. 7)

(2)

$\begin{array}{llll}\text { ghan̄i vāri } & \text { mātangim } & \text { vidyā } & \text { kahī } \\ \text { many times } & \text { outcaste.Instr. } & \text { knowledge.fem.sg. } & \text { say.PPP.fem.sg. } \\ \text { Many times the outcaste (A) taught (him). 15 } & \text { c AD (R.G. 15) }\end{array}$

(3)

rāi na grahau narasimha

king.Instr. not catch.PPP.masc.sg. N.masc.sg.

King did not catch Narasingh (O). $15^{\text {th }} \mathrm{c}$ AD (R.G. 27)

$\begin{array}{lllll}\text { ehavau } & \text { prabhāv } & \text { sāmbhạ̄i } & \text { kumār } & \text { kahiu } \\ \text { Such } & \text { power } & \text { hear.adv.part. } & \text { prince.Nom.sg. } & \text { say.PPP.masc.sg. } \\ \text { Having heard about such power prince (A) said. } 16^{\text {th }} \text { c AD (R.G. 36) }\end{array}$

One of the implications of ergativity, namely the equal treatment of A and Obl. arguments (cf Figure 1) has been attested in Old Rajasthani as well - in texts from the $15^{\text {th }}$ century AD both A and Obl. are marked with Instr. (cf. KHoкHLovA 1992: 75; 1995: 122). This, nevertheless, was a short-lived phenomenon due to attrition of the Instr. marking of A.

\begin{tabular}{|c|c|c|c|c|c|}
\hline $\begin{array}{l}\text { tīṇaim } \\
\text { this.Instr. } \\
\text { van-nā } \\
\text { forest.Post.Gen }\end{array}$ & $\begin{array}{l}\text { mātaṃgim } \\
\text { outcast.Instr. }\end{array}$ & $\begin{array}{l}\text { avanāminī } \\
\text { bending }\end{array}$ & $\begin{array}{l}\text { vidyā-naim } \\
\text { knowledge.Gen. }\end{array}$ & $\begin{array}{l}\text { balim } \\
\text { power.Instr. }\end{array}$ & $\begin{array}{l}\text { sabartuk } \\
\text { all.season }\end{array}$ \\
\hline $\begin{array}{l}\text { āmbā -n̄̄ } \\
\text { mango.pl.Gen. } \\
\text { pūriyu } \\
\text { fulfill.PPP.masc }\end{array}$ & $\begin{array}{l}\text { ḍạ̣ } \\
\text { branch } \\
\text { s.sg. }\end{array}$ & $\begin{array}{l}\text { namāṝi } \\
\text { bend.abs. }\end{array}$ & $\begin{array}{l}\text { āmbā } \\
\text { mango.pl }\end{array}$ & $\begin{array}{l}\text { leī } \\
\text { take.abs. }\end{array}$ & $\begin{array}{l}\text { dohalu } \\
\text { craving.masc.sg. }\end{array}$ \\
\hline
\end{tabular}

In perfective tenses at the stage of early Marwari $\left(15^{\text {th }} \mathrm{c} A D\right)$ pronouns in the A function were marked by the Instr. while those in the O function remained unmarked (see (6) and (7); cf. KHOKHLOva 1993: 80; 1995: 23). There is evidence of the earlier opposition agentive vs. non-agentive $1^{\text {st }}$ pers. pron. haum - maim. The oblique pronominal $\mathrm{O}$ marking which had initially occurred in the non-perfective domain spread to the perfective one, preserving the OV number agreement. This process had started at a relatively early stage, but was completed probably around the beginning of the $18^{\text {th }}$ century (Marwari texts from that period still show unmarked pronouns in the $\mathrm{O}$ function).

$\begin{array}{lllll}\text { kumār lakuțai te } & \text { tim hanyā } & \text { jim } \\ \text { prince wood.Instr.sg. } & \text { they.Nom. } & \text { so } & \text { beat.PPP.Nom.pl.masc. } & \text { That } \\ \text { Prince beat them so that... (R.G. 39) } & & \end{array}$




$\begin{array}{lll}\text { taim } & \text { amhe ihām chatā } & \text { jāṇiyā } \\ \text { you.Inst. } & \text { we.Nom. here being.PPresA.masc.sg. } & \text { recognize.PPP.Nom.pl.masc. } \\ \text { You recognized us who were here. (R.G. 11) } & \end{array}$

The opposition A/S existing in the perfective aspect in Old Rajasthani in the whole plural paradigm became restricted to masc. nouns in - $O$ and to plural nouns terminating in consonants. Therefore only these classes of nouns have preserved the ergative (or tripartite $\mathrm{A} \neq \mathrm{S} \neq \mathrm{O}$ ) marking pattern in the majority of the contemporary dialects of Rajasthan. However despite the fact that standard grammars of Marwari prescribe employment of the agentive case for nouns terminating in -o (LĀḶAs 1997: 45; but MAGIER (1983: 311-312) maintains that only $3^{\text {rd }}$ pers. pronouns constitute an ergative residue in the Marwari case marking), the practice is not even followed by writers (cf. KHOKHLOVA 1995: 20-21), not to mention ordinary speakers.

The same pertains to the other varieties of Rajasthani which have not employed the ergative postposition, thus not following the standard Hindi template, e.g. Shekawati (8):

$$
\begin{aligned}
& \mathrm{t} \int^{\mathrm{h}} \text { oro/ } \mathrm{t} \int^{\mathrm{h}} \text { ora kela mol lija } \\
& \text { boy.Dir./Obl. } \quad \text { banana.pl price take.PPP.masc.sg } \\
& \text { A boy bought bananas. (Shekawati; author's field notes) }
\end{aligned}
$$

GrIERSON 2005 [1908], vol. IX, part II: 45, 52, 55) remarked that only Malwi and Mewati used the nai postposition as an agentive marker, although in both dialects it could serve as Dat./Acc. postposition as well (though rarely in Malwi).

The employment of the ne postposition marking A in Rajasthani seems to be a recent development which took place under the influence of the neighboring Western Hindi dialects, but it has been consistently noted in the most recent grammars of the dialects such as Marwari, Shekawati, Mewati (GuSAIN 2004; 2001; 2003), Harauti (SHARMĀ 1991). Among them Marwari and Shekawati, which are said not to possess the ergative postposition at all (cf. AgRAVĀL 1964: 82; LĀḶAs 1994: 40-41; 1997: 44), seem to have inconsistently employed the new agent marking (my Shekhawati and Marwari respondents ${ }^{2}$ occasionally produced sentences with the ergative postposition, but when confronted with such sentences produced by the present author they would judge them ill-formed). DAs (2006: 141, 150) however gives all the examples from his own fieldwork on Marwari OV agreement with the agentive postposition which at the same time functions as a Dat. marker (9): ${ }^{3}$

$$
\begin{aligned}
& \text { hərI ne məlik ne pasa } p e \text { dija } \\
& \text { servant Post.Erg. master Post.Dat. money.masc. pl. find.part.adv. give.PPP.masc.pl. } \\
& \text { The servant returned money to the master. (DAs 2006: 141) }
\end{aligned}
$$

Undoubtedly the labile status of the agent marking indicates a transitional stage in the development of the ergative pattern in Rajasthani dialects. One of the most interesting phenomena can be observed in Harauti, where employment of the agentive postposition seems

2 My Shekhawati informers were inhabitants of Mahensar and Mandawa, while for Marwari I interrogated speakers from Pokharan and Jodhpur.

3 The examples given by Das should be treated with considerable caution, since they contradict all the rules mentioned in the vernacular grammars of Marwari (cf. LĀtas 1994; 1997). It seems to me that Das' respondents were influenced by the questionnaires written in Hindi. 
to be in complementary distribution with the standard Acc./Dat. usage (see ex. (10) and (11) from Harauti, cf. also AlLEN 1960: 10; SHARMa 1991: 191).

$\begin{array}{llll}\text { t } \int^{\mathrm{h}} \text { oro } & \text { sãp } & \text { ne } & \text { marjo } \\ \text { boy } & \text { snake.masc. } & \text { Post.Dat./Acc. } & \text { hit.PPP.masc.sg. } \\ \text { A boy hit the snake. } & \text { (Harauti) (SHARMĀ 1991: 161) }\end{array}$

$$
\begin{array}{lllll}
\mathrm{t} \int^{\mathrm{h}} \text { ord } & \mathrm{n} \varepsilon & \text { sãp } & \mathrm{i} & \text { marjo } \\
\text { boy.Obl. } & \text { Post.Dat. } & \text { Snake.masc. } & \text { emph. } & \text { hit.PPP.masc.sg. } \\
\text { A boy hit the snake. } & \text { (Harauti) } & \text { (SHARMĀ } & \text { 1991: 161) }
\end{array}
$$

What is more, some of the speakers of Harauti allow the parallel oblique marking, i.e. simultaneous $\mathrm{A}$ and $\mathrm{O}$ marking by the postposition ne. According to my informants, however, this usage (12) is accepted only marginally. In fact in the languages of the world the same A and O marking is considered either impossible (cf. COMRIE 1978: 329-335) or very rare, i.e attested in Pamir languages and in Kashmiri (cf. BubeniK 1989a: 182; PAYNe 1980; SKALMOWSKI 1974). Such double oblique marking can be traced in selected contemporary dialects belonging to Western Hindi, namely Haryanvi, Ahirvati.

$$
\begin{aligned}
& \begin{array}{lllll}
\mathrm{t} \int^{\mathrm{h}} \text { ori } & \mathrm{n} \varepsilon & \mathrm{t} \int^{\mathrm{h}} \text { ora } & \mathrm{n} \varepsilon \quad \operatorname{dek}^{\mathrm{h}} \mathrm{jo}
\end{array} \\
& \text { girl Post.Erg. boy.Obl. Post.Dat. hit.PPP.masc.sg. } \\
& \text { A girl saw the boy. (author's field notes) }
\end{aligned}
$$

All the contemporary Rajasthani dialects have lost the A/S distinction in the $1^{\text {st }}$ pers. pron. and have maintained it in the $2^{\text {nd }}$ and $3^{\text {rd }}$ or only $3^{\text {rd }}$ pers. pron. In standard Marwari even the use of the $3^{\text {rd }}$ pers. pron. appears to be optional - cf. examples (13) and (14) taken from the monthly Mānak.

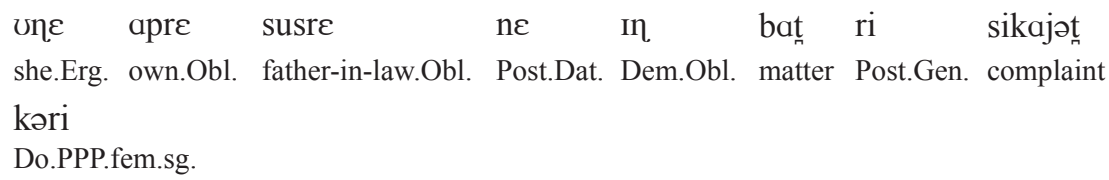

$$
\begin{aligned}
& \text { vo uñ̃ } \quad \text { sũ } \quad \text { put } \int^{h} \text { ijo } \\
& \text { he they.Obl. Post.Abl. } \\
& \text { Post.Dat. } \\
& \text { He (king) asked him (Brahman). (Marwari) (Māṇak 2008, Jan. 50) }
\end{aligned}
$$

Contrary to Western Hindi dialects, Marwari preserved OV agreement despite introducing $\mathrm{O}$ marking (cf. (15)). This has been perceived by some scholars as a residue of ergativity at the syntactic level (cf. KHoKhlova 1995: 31-32). Much more intricate, however, is the formation of the so-called 'split agreement' (16) - the simultaneous development of the AV agreement (A agrees with the auxiliary) and maintenance of the $\mathrm{OV}$ agreement $(\mathrm{O}$ agrees with the participial from of the verb). ${ }^{4}$

4 There has been considerable discussion regarding this phenomenon (cf. MAGIER 1983: 321-323; BAHL 1989: 157-158). ALLEN (1960) found this pattern only with the $1^{\text {st }}$ person, but according to BAHL (1972: 15) this 

sundarī-nai
bharathai
rākhī
beautiful woman-Post.Acc. Bh.Instr. keep.PPP.fem.sg.

Bharath kept the beautiful woman.

(Old Marwari from Tessitori 1979 [1914-1916]: 155)

$$
\begin{aligned}
& \text { mhẽ } \varepsilon r i \quad \text { dukanã } \operatorname{dek}^{\mathrm{h}} \mathrm{i} \quad \text { hũ } \\
& \text { I such shop.fem.pl. see.PPP.fem. be.aux. } 1^{\text {st }} . \text { sg. } \\
& \text { I have seen also this kind of shops. (Mānak 2008, Jan. 44) }
\end{aligned}
$$

Although Rajasthani dialects both old and contemporary can be interpreted only as syntactically accusative (and partly morphologically ergative), there are several tendencies which indicate a general drift towards nominativity at the syntactic level as well. Among them the transition from pivotless towards $\mathrm{A} / \mathrm{S}$ pivot language will be dealt here briefly.

The transition from pivotless towards A/S pivot language indicates that ergativity had once penetrated the syntax of MIA and early NIA to such an extent that the language lost the stability of the syntactic pivot, or in other words became close to the 'pivotless' language type in which the basic syntactic operations are not consistently controlled either by the A/S pivot (accusative type) or by the S/O pivot (ergative type) (cf Dixon 1994: 143).

In the early Marwari texts there are attestations of conjunction reduction which indicate the existence of two types of pivot, namely A/S and S/O pivots ((17) and (18)). The $\mathrm{S} / \mathrm{O}$ pivot, which is a characteristic of an extremely small number of syntactically ergative languages, is absent in the contemporary IA languages, but relics of it can still be found in early Western Hindi and even early Eastern Hindi texts. What is more, in texts from the $18^{\text {th }}$ century one can still find instances indicating pivot instability - in ex. (19) the pronoun is co-referential not with the leftmost Nom. A but with the Acc. object. Ex. (20), on the other hand, conforms to the general pattern of modern IA languages where pron. is co-referential with the Erg. A. It is not the purpose of this paper to question the relevance of the category of subject in the early stages of the NIA languages, but its status is not obvious.

$$
\begin{aligned}
& \text { ti sarve tịni jitā rājpurī āpṇi karī baiṭau } \\
& \text { They all he.Obl. defeat.PPP.masc.pl. Rajpuri own make.abs. sit.PPP.masc.sg. } \\
& \text { He (A) defeated all of them and having appropriated Rajpuri (S) sat (on the throne). } \\
& \text { (R.G. 6) } \\
& \text { or }
\end{aligned}
$$

They are all defeated by him, having appropriated Rajpuri, (he) sat (on the throne). (KHOKHLOVA 2001: 177)

$$
\text { ghạ̣̄ vāri mātãgĩ vidyā kah̄̄ puṇ āvai nah }
$$
many times outcaste.Instr. knowledge.fem.sg. say.PPP.fem.sg. but come.pres.3sg. not Many times the outcaste taught (him) the knowledge (O) but it (S) does not come (i.e. it is not remembered). (R.G. 15) (KHOKHLOva 2001: 177) 


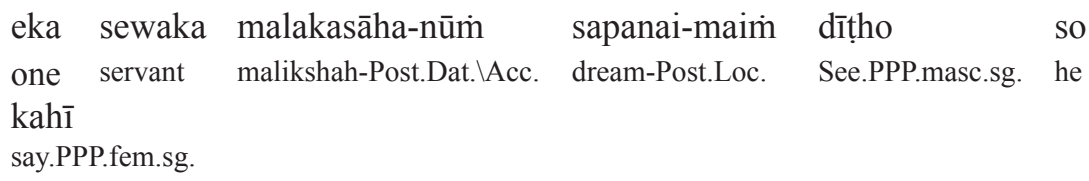

One servant saw Malik shah in his dream and he (Malik shah) said. (Marwari $18 \mathrm{c}$ AD (R.G. 74))

$\begin{array}{lllll}\text { kin̄ī gunāha kiyo } & \text { tho, } & \text { so } & \text { bhāga gayo } \\ \text { who.Obl. sin } & \text { do.PPP.masc.sg. } & \text { be.Past.masc.sg. } & \text { that } & \text { run away go.PPP.masc.sg. } \\ \text { Somone who committed sin, ran away. (Marwari } 18 \text { c AD (R.G. 74)) }\end{array}$

\section{'ERGATIVE SUBJECTS' IN CENTRAL PAHARI - REINFORCEMENT OF ERGATIVITY}

Several attempts to reconstruct the possible path of development of the grammatical system of Central Pahari languages have already been made by SHARma $(1985 ; 1987)$ for Kumauni; an extensive etymological survey has been made as well, but again only for $\mathrm{Ku}-$ mauni (RuVĀLì 1983).

Old Kumauni ( $19^{\text {th }}$ century) shows consistently different Nom. and Obl. marking only for - $o$ stems (the other stems maintained Nom. vs. Obl. opposition only in the plural). There is no separate synthetic agent case (Instr.) as can be observed in Rajasthani stems in - $o$ and in earlier stages also in other stems, but cases are formed by means of postpositions which are attached to the noun in oblique case. GrIERSON 2005 [1916], vol. IX, part IV: 109) noted that only standard dialect (spoken in the vicinity of Almora) and dialects of Kali Kumaun, i.e. Kumaian, had fully preserved terminations of nouns and verbs, while the Khasparjiya dialect did not.

The majority of the modern dialects of Kumaon (except the Eastern dialects) continue the process which was initiated in Khasparjiya, i.e. they have lost oblique case ending in the -o stems in singular, marking oblique only by umlaut (cf. SHARMa 1987: 32-33). By analogy the nominative form has been leveled to the oblique one.

In the western dialects the former postpositions have actually become case endings (Sharma 1987: 43-44). On the other hand the eastern dialects appear to be more conservative and they have preserved the opposition Nom. vs. Obl. in the - $O$ stems and the postpositions in their full forms.

In the perfective domain already in Old Kumauni one can observe separate agent marking by the -le postposition, which at the same time was employed as the Instr. marker.

The ergative construction with unmarked $\mathrm{O}$ has exactly the same pattern as in standard Hindi - there is OV agreement (see ex. (21)), S is always in the direct case (22). It is however interesting that even animate objects remain unmarked, which actually conforms to the general tendency observed in Rajasthani that the object markers are introduced into the perfective domain after they have been well established in the imperfective one.

$$
\begin{aligned}
& \text { pròthvī-mẽ lag yo pahāṛ hamarī thātī racī dev-le } \\
& \text { earth-Post.Loc. too this mountain our.fem. place to live make.PPP.fem. god.Post.Erg. } \\
& \text { On the earth the god (A) made also this mountain our place to live. (19 } 9^{\text {th }} \text { century } \\
& \text { poem of Gumānī Pant from JuYĀL 1973: 168) }
\end{aligned}
$$




$\begin{array}{llllll}\text { tadapi muluk tero chội nai koī bhājā } \\ \text { thereupon } & \text { country your leave.abs. } & \text { not } & \text { who } & \text { run away.PPP.masc. }\end{array}$

Thereupon, nobody $(\mathbf{S})$ having left your country ran away. $\left(19^{\text {th }}\right.$ century poem of Gumān̄̄ Pant from JuYĀL 1973: 166)

It seems that the lack of a synthetic instrumental case has been compensated by the employment of the agentive postposition. It is therefore a return to the point of departure, namely to the original instrumental agent marking which could be observed in Old Rajasthani and, what is more, with the instrumental function preserved. As we could see in the section on Rajasthani, the equal treatment of A and indirect objects has been perceived as an implication of ergativity. However in the history of Rajasthani one can observe the loss of the Erg. and Instr. syncretism, while in Pahari it has been consistently maintained or, in other words, it has been reinforced by introducing the Erg./Instr. postposition le. The instrumental marking is not in complementary distribution with the ergative one: cf ex. (23), which is the continuation of (21).

$$
\begin{aligned}
& \text { yeī citt vicāri } \quad \text { kāphal sabai rātā bhayā krodh-le } \\
& \text { this.empf. mind contemplate.abs. kāphal fruit all red.pl. be.PPP.pl. anger-Post.Instr. } \\
& \text { Having contemplated it in mind, all the kaphāl fruits turned red from anger. } \\
& \left(19^{\text {th }} \text { century poem of Gumānī Pant from PANDE } 1994: 21\right)
\end{aligned}
$$

The pronominal marking of Kumauni in the ergative domain actually differs from the nominal system only in $\mathrm{O}$ marking. As has been mentioned, the nominal $\mathrm{O}$ in perfective tenses remained chiefly unmarked. Pronouns on the other hand introduced Acc. marking from the imperfective to perfective domain at an earlier stage. From the earliest sources the existence of the tripartite system $(A \neq S \neq O)$ can be noted. In Old Kumauni, however, instances of employment of the synthetic oblique in the $\mathrm{O}$ function can still be traced - they are restricted to the objects governed by absolutives; otherwise in the ergative construction pronouns usually take Dat./Acc. postposition (see ex. (24) comprising the oblique form of $1^{\text {st }}$ pers. sg. which is equal to Nom., $1^{\text {st }}$ pers. pronoun with Acc./Dat. postposition and the oblique form of $3^{\text {rd }}$ pers. pron. pl. which functions here as Dat.). The unmarked forms of pronouns are attested in the $\mathrm{O}$ function as well but, as is worth mentioning here, they maintain the person agreement with the verbal form. This type of agreement also occurs in Garhwali (see ex. (25) and (26)).

It seems, however, that the more ancient stage of development can be traced in Western Pahari. For example, Kului preserves the opposition of the agentive and non-agentive $1^{\text {st }}$ pers. pronoun maí vs. $h \bar{a} \tilde{\bar{u}}$ the former being employed only to mark $\mathrm{A}$ in the perfective tenses. In addition, there is a postpositional Dat./Acc. form which can also be employed in the $\mathrm{O}$ function, thus forming a tripartite system (cf. ṬHĀKUR 1975: 251-254).

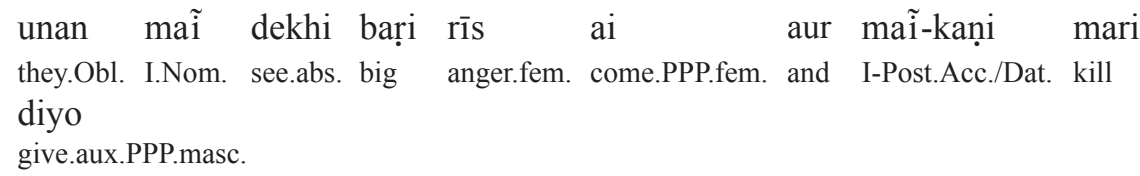

Having looked at me they became very angry and they killed me. (Standard Kumauni) (GriERSON 2005 [1916], vol. IX, part IV: 172) 


$\begin{array}{lccc}\text { vai-n } & \text { maĩ māryũ } & \text { Garhwali } \\ \text { u-le } & \text { maĩ māryũ } & \text { Kumauni } \\ \text { he-Post.Erg } & \text { I } & \text { hit.PPP.1sg. } & \\ \text { He hit me. } & \text { (JuYĀL } 1973: 141) & \\ \text { maĩ -n } & \text { vo māre } & \text { Garhwali } \\ \text { I.-Post.Erg } & \text { he } & \text { hit.PPP.3sg. } & \\ \text { maĩ -le } & \text { u } \quad \text { māro } & \text { Kumauni } \\ \text { I.Post.Erg } & \text { he hit.PPP.masc.3sg. } & \\ \text { I hit him. (JuYĀL 1973: 141) } & \end{array}$

In the area of nominal case marking, contemporary Pahari dialects do not differ considerably from the languages recorded over a century ago by Grierson (and in the case of Kumauni more than 150 years ago, if we take into consideration the language of the early

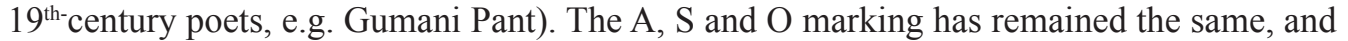
the only difference can be observed in the phonetic shape of the former postpositions. In the majority of the central Pahari dialects they have actually become case endings - e.g. in western Kumauni -ne>-n, le >-el, -l (Ag./Instr.), $k o>-a k$, $-k$ (Gen.), $m \bar{e}>-m$ (Loc. in western Kumauni) (Sharma 1987: 43-44) in Garhwali -ne> - n, le $>-l$ (Ag./Instr.), $-k o>-k$ (Acc./ Dat.) (BIșT \& Jośī 2005: 16; PUROHIT \& BeÑJvÂL 2007: 57, 252). The process of the evolution of postpositons started in the $19^{\text {th }}$ century (probably in the second half of that century), as we can infer from the data gathered by Grierson and from the oldest poems. The phonetic change, however, has not affected the split ergative pattern.

On the other hand Western Pahari dialects have not introduced a separate agentive postposition, thus here the agent marking is more conservative and the ending $-e$ is a direct descendant from the OIA/MIA Instr. (MAsica 1991: 232, 247).

Unlike Rajasthani, Pahari dialects still preserve the unmarked pronominal $\mathrm{O}$ in the ergative domain. It must be emphasized, though, that central dialects, i.e. Kumauni and Garhwali, especially in their standardized version, have already consistently introduced $\mathrm{O}$ marking. In the Kumauni spoken around Almora (i.e. Khasparjiya), which is considered the standard language, I have not come across any instances of unmarked $O$. The same pertains to the Garhwali spoken in the area of Śrinagar. The literary works available to me also confirm this tendency. There are however dialects which still preserve unmarked $\mathrm{O}$ in the perfective tenses. SHARMA (1987: 97) gives a few examples of the employment of unmarked pronominal objects at par with the marked ones, but he does not specify in which dialects they are in use. ${ }^{5}$ I have found examples of unmarked pronominal objects in the perfective tenses in the Gangoli subdialect of Kumauni (ex. (27)). It can be expected that the spread of the Acc. marking will soon oust the unmarked $\mathrm{O}$ from the pronominal system of central Pahari. In this respect Western Pahari languages appear to be much more conservative. Kului still employs unmarked personal pronouns in the $\mathrm{O}$ function in the perfective tenses along with the marked forms.

$$
\begin{array}{lll}
\text { ram- } \varepsilon l & \text { mũ } & \operatorname{dek}_{\text {hjũ }} \\
\text { Ram.Post.Erg. I } & \text { see.PPP.1sg. } \\
\text { Ram saw me. (Gangoli) (Author's field notes) }
\end{array}
$$

5 JUYĀL (1973), who based his research chiefly on the standard dialect as recorded by Grierson, also does not give any details regarding the use of the unmarked pronominal $\mathrm{O}$. 


$\begin{array}{lllll}\text { mero bāp } & \text { pātāla-ko } \quad \text { raja } & \text { bisnu-le } & \text { màri-dechh } \\ \text { my father } & \text { Patala-Post.Gen. king } & \text { Vishnu-Post.Erg. kill-aux.give.3sg. } \\ \text { wī-ko } \quad \text { kwe } & \text { chyŏlo nhàti } & & \\ \text { he-Post.Gen. any } & \text { son } & \text { be.3sg.neg } & & \end{array}$

Vishnu killed my father king of Patala. He (king of Patala) has no son. (Kumauni) (GRIERSON 2005 [1916], vol. IX, part IV: 175)

\begin{tabular}{|c|c|c|c|c|}
\hline dzosse la & sũ̄rI & $b^{\text {fi }} \varepsilon-k$ & semnI & puji \\
\hline as soon as rec & little & brother.Post.Gen. & Front & reach.PPP.fem.sg. \\
\hline wi-l & jore-1 & svつte-1 & maro & \\
\hline
\end{tabular}

As soon as the red pig (S) came to the front of the little brother, he (i.e. brother) beat (her) (O) vehemently. (PANT 2006: 150)

\begin{tabular}{|c|c|c|c|c|}
\hline etuk & nen & $\mathrm{b}^{\mathrm{h}} \mathrm{\jmath}-\mathrm{k} \tilde{\varepsilon}$ & $\mathrm{t}^{\mathrm{h}}$ oriber terI & sesul \\
\hline so & Small & infant.Post.Dat./Acc. & leave.abs. your & mother-in-law \\
\hline tU-kẽ & & kIle & $\log \alpha$ & \\
\hline you-P & Dat.Acc. & Why & send.PPP.masc.sg. & \\
\hline
\end{tabular}

(You) $\left(\mathbf{A}_{1}\right)$ having left so little infant $\left(\mathbf{O}_{1}\right)$, why did your mother-in-law $\left(\mathbf{A}_{2}\right)$ send you $\left(\mathbf{O}_{2}=\mathbf{A}_{1}\right)$ (here)? (PANT 2006: 58)

mantri-1 jeber radzkumar- $\mathrm{t}^{\mathrm{th}} \tilde{\varepsilon} \quad \operatorname{putg}^{\mathrm{h}} \mathrm{\jmath}$

minister-Post.Erg go.abs prince-Post.Abl. ask.PPP.masc.sg.

Minister, having gone, asked the prince. (PANT 2006: 20)

\section{POSTPOSITIONAL MARKERS AND OBLIGATORY CONSTRUCTIONS}

In Rajasthani, before the Dat./Acc. postposition was employed in the obligatory construction, A had been marked by Instr. and the verbal form was gerundive (I could find only one clear example (34) with marked A from a prose text from the $16^{\text {th }}$ century AD). Later, around the $18^{\text {th }}$ century, postpositional marking ousted the synthetic Instr. and gerundive yielded to gerund/infinitive. In the example (35) the two forms, namely gerundive and gerund/infinitive, are still in use (apart from that, (35) is an example of conjunction reduction controlled by the Instr. pronoun, which makes it an eligible candidate for the subject). The ne postposition, being originally the dative marker, is still used in those dialects which have not employed the Acc./Dat. postposition ko (e.g. Mewati, and in some varieties of Marwari; see (36)).

The usage of the ne postposition in this function seems to have once been spread among a greater number of dialects, as is confirmed by the classical Dakkhini data (ŠAMATOv 1974: 233). (Formally it resembles the obligatory construction which is spreading now in colloquial Hindi, presumably under the influence of Punjabi - the Erg. postposition ne ousts the Dat. marker of standard Hindi i.e. ko; the topic has been widely discussed by BASHIR 1999). 
taïm māharoparodhi pakșa eka yakșa-nī pūjā variwī you.Instr. my shelter side one Y.-Post.Gen. worship choose.ger.fem.sg. You have to worship Yaksha in one corner of my shelter. 16 c AD (R.G. 37)

$$
\begin{array}{llllll}
\text { piṇa au dhanuṣa } & \text { mo-nūm } & \text { cāḍhaṇo } & \text { sītā paraṇawī } \\
\text { but this } & \text { bow } & \text { I.Obl.-Post.Dat. } & \text { lift.inf } & \text { S. } & \text { marry.ger.fem.sg. }
\end{array}
$$

But I have to lift the bow and marry Sita. 18 c AD (R.G. 97)

$\begin{array}{llll}\text { bin-ne } & \text { roti } & \mathrm{k}^{\mathrm{h}} \mathrm{ani} & \mathrm{h} \varepsilon \\ \text { he.Post.Dat. } & \text { bread.fem } & \text { inf.fem. } & \text { be.aux.3sg. }\end{array}$

He has to eat the bread. (Shekhawati) (Gusain 2001: 39)

From the earliest records of Kumauni we can infer that the le postposition was employed in the obligatory constructions in which Rajasthani dialects used to employ the Dat./ Acc postposition ne. In one of the Rajasthani dialects, namely Mewati, there is a Dat./Acc postposition $l u$ which seems to be an etymological equivalent to the Pahari le (the postpositional parallels Acc./Dat. $n \bar{u} \dot{m}-l u$ vs. Erg. $n e-l e$ are evident). ${ }^{6}$ But it has to be emphasized here that the use of the agentive postposition in this context was restricted, and Old Standard Kumauni shows a preference for the Dat./Acc postposition. Grierson's data shows 4 occurrences of the dative marked agent and 1 of the ergative marked agent in obligatory construction with the impersonal chāiṇo 'it is necessary' (Hin. chahiye) ${ }^{7}$; there is only one example of the obligatory construction with the bare infinitive where agent is overtly expressed, and it is marked by the ergative postposition.

Contemporary Central Pahari languages employ the agentive postpositions to mark A in the obligatory construction based on the infinitive verbal form (see ex. (37) and (38)). Nevertheless, it seems that there is a minute semantic distinction between Garhwali and Kumauni, although it is not recognized by all authors - cf. JUYĀL (1973: 146-147), who treats it in Kumauni and Garhwali as obligative future, and SHARma (1987: 111), who states that the construction of the type represented by (38) is present obligatory. My own field study carried out in 2008, and study of the available prose texts, tends to confirm the maintenance of the distinction, i.e. present obligatory in Kumauni and future obligatory (tending towards simple future) in Garhwali, which I render here in translation; in this respect the Garhwali pattern is of a Western Pahari type (cf. ex (39) from Kului with the stipulation that in Kului it is simple future (ṬHĀKUR 1975: 304-305)).

$$
\begin{aligned}
& \text { ram-ən } \quad b^{\mathrm{h}} \mathrm{ol} \quad \text { dehradun jãn } \\
& \text { I.Post.Erg. tomorrow Dehradun go.inf. } \\
& \text { Tomorrow Ram will (have to) go to Dehradun. (Garhwali) (author's field }
\end{aligned}
$$

${ }^{6}$ It is Mewati which has been perceived from the very beginning as the dialect bearing the strongest affinities with the Pahari dialects (cf. GrIERSON 2005 [1916], vol. IX, part IV: 10).

7 The only dialect showing both Dat./Acc. and Erg. A marking is Pachai (and the only occurrence of Erg. is attested with pronoun). Other dialects employ exclusively the Dat./Acc. postposition with chāiṇo 'it is necessary'. 


$$
\begin{array}{lllll}
\text { t jjpl-el } & \text { jə } & \text { kam } & \text { kərən } & \text { tə } \\
\text { son.Post.Erg. } & \text { this } & \text { work } & \text { do.inf. } & \text { be.aux.3sg. }
\end{array}
$$

The son has to do this work. (Kumauni) (author's field notes)

$$
\begin{array}{lll}
\text { Johru-e } & \text { bute } & \text { katne } \\
\text { son.Post.Erg. } & \text { tree.pl } & \text { cut.inf.pl }
\end{array}
$$

The son will cut the trees. (Kului) (ṬHĀKUR 1975: 305)

It is remarkable that the pronominal Erg. forms are not used in the simple future in Western Pahari as they are in the future obligatory in Garhwali, instead special Instr. forms are employed (cf (40) and (41)).

$$
\begin{aligned}
& \text { tom-un kətka din jək }{ }^{\mathrm{h}} \text { ron } \\
& \text { you.Erg. how many day here stay.inf. } \\
& \text { How many days will you stay here. (Garhwali) (Author's field notes) }
\end{aligned}
$$

$$
\begin{aligned}
& \text { mũ } \quad \text { sona } \\
& \text { he.Instr. } \quad \text { sleep } \\
& \text { I will sleep. (Kului) (ṬHĀKUR 1975: 252) }
\end{aligned}
$$

One can notice that in contemporary dialects the instrumental marking of A in the obligatory construction is being replaced by Dat./Acc. marking, thus moving closer to the standard Hindi pattern (42). Likewise in Nepali the use of the Dat. postposition in the obligatory construction is an innovation (WALLACE 1985 quoted by MASICA 1991).

$$
\begin{aligned}
& \text { mI-ke jə kam kərən } \text { th }^{\text {h }} \text {, } \\
& \text { I-Post.Dat./Acc. this work do.inf. be.aux.3sg. } \\
& \text { I have to do this work. (Kumauni) Author's field notes }
\end{aligned}
$$

\section{IN SEARCH OF SOURCES...}

The ergative pattern existing in Pahari is somehow more resistant to nominativization. The transition from the synthetic to analytic type has not disturbed the ergative pattern. The renewal of the earlier construction based on the -ta participle with Instr. agent, the renewal of the obligatory construction based on the gerundive, and preservation of $\mathrm{OV}$ agreement (the coding properties) are clear indicators of the maintenance of split ergativity. On the other hand, the instability of the syntactic pivot (behavioral properties) points either to weak syntactic ergativity or to the pivotless type.

The evolution from ergative to nominative type has been widely attested in many languages of the world and it is traceable in many tongues belonging to the Indo-Iranian family. The reverse development, although accepted by many specialists in IA languages, was rejected by typologists who dealt extensively with active and ergative languages. For example, KLIMOV (1973) in his monumental monograph on ergativity not only refused to accept the accusative-to-ergative shift, but claimed that the ergative pattern had been simply borrowed 
by IA tongues from the neighboring languages. The proposed Proto-Burushaski (KLIMOV 1976) or Tibeto-Burman substrata were however rejected (TiKKANEN 1988). However, an interesting proposal was put forward by ZAKAHRYIN (1979), who formulated a hypothesis of active typology of the colloquial dialects which were in contrast with a 'standard' IA language of nominative typology whose ergativization was a by-product of language contact with Tibeto-Burman tongues. It could have been a Dardic tongue or tongues with presumably strong active traits (ZAKHARYIN 1982: 42) or an unknown language ' $X$ ', whose existence was once postulated while analyzing the unidentifiable layers of agricultural vocabulary in NIA (Masica 1979).

On the other hand there is a lexical evidence which can be perceived as an active residue, namely verbs of the type khãsnā 'cough' - so-called eventives, i.e. verbs denoting something happening to or taking place in a person (or object), affecting a person (or object) (GoNDA 1951: 82-100; 1960a: 49-55). Notwithstanding the fact that they are intransitive, they do take the ergative $\mathrm{S}$ in the perfective tenses. This group of verbs has been attested in other languages belonging to the ergative type (LAZARD 1998: 136-139) and certainly at least in one language family, namely Caucasian, they constitute an archaic layer of a former active type (cf. KLIMOV 1973: 144-148, 232-234).

The IA evidence is modest but partly traceable historically; for example, in Old Awadhi there are instances of the usage of the verb hãsna 'laugh' with S in Nom. or in Obl. but neutral form of the PPP (see (43) and (44)).

$$
\begin{aligned}
& \text { teï hamsā } \\
& \text { s/he.Obl. laugh.PPP.masc.sg. } \\
& \text { He laughed. Jaysi Padumāvati } 23.8
\end{aligned}
$$

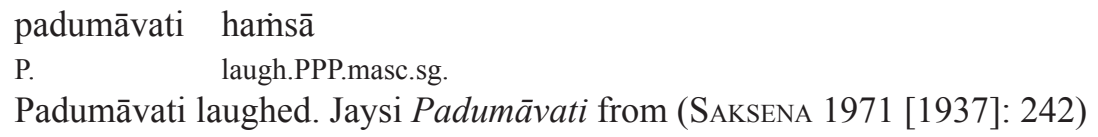

In the contemporary IA languages that preserve the ergative pattern, eventive verbs take S either in Nom. or Erg., the latter being more archaic. It is thus a question of further historical investigation whether the assumed 'active residue' is a substratal layer or the preserved earlier pattern. In the case of syntactic phenomena such as ergative and obligatory construction, it has been recently suggested that they repeat the older pattern (Latin mihi est construction) attested widely in other IE languages and constituting a basis for reconstruction of the active stage of PIE (BAUER 2000).

\section{REFERENCES}

AgraVĀL Kailāś Candr. 1964. Śekhāvāṭ̄ bolī kā varnatmak adhyayan. Lakhnau: Lakhnau Visvavidyālay. Allen W. Sidney. 1960. "Notes on Rājasthānī Verb.” Indian Linguistics 21, 4-13.

BAHL Kali Charan. 1972. "On the Present State of Modern Rajasthani Grammar.” Parampara 1-76. BAHL Kali Charan. 1989. Ādhunik rājasthān̄i saṃracnātmak vyākaraṇ. Jodhpur: Rājasthānī sāhiya saṃsthān. BAUER Brigitte. 2000. Archaic Syntax in Indo-European. Berlin-New York: Mouton de Gruyter. BEAMES John. 1970 [1872-1879]. A Comparative Grammar of the Modern Aryan Languages of India. New Delhi: Munshiram Manoharlal. 
BHĀNĀVAT Narendra, KAMAL Lakshmi (eds.). 1997-1998. Rājasthān̄̄ gadya: vikās aur prakāś. Āgrā: Śrīrām Mehrā end Kampanī. (R.G.)

Bhaskararao Peri, Subbarao Karumuri Venkata (eds.). 2004. Non-nominal Subjects. Amsterdam: John Benjamins.

BıșT Śersinh, JośṬ Surendr. 2005. Janpadīy bhāṣāa-sāhitya. Haldvānī: Ankit Prakāśan.

BLoch Jules. 1965. Indo-Aryan from the Vedas to Modern Times. Paris: Adrien Maisonneuve.

Bubenik Vit. 1989a. "An Interpretation of Split Ergativity in Indo-Iranian Languages.” Diachronica 6(2), 181212.

BUBENIK Vit. 1989b. "On the Origins and Elimination of Ergativity in Indo-Aryan Languages." Canadian Journal of Linguistics 34(4), 377-398.

Bubenik Vit. 1993. "Morphological and Syntactic Change in Late Middle Indo-Aryan." The Journal of IndoEuropean Studies 21(3-4), 259-281.

Bubenik Vit. 1996. The Structure and Development of Middle Indo-Aryan Dialects. Delhi: Motilal Banarsidass.

BubenIK Vit. 1998. A Historical Syntax of Late Middle Indo-Aryan (Apabhramśa). Amsterdam-Philadelphia: John Benjamins.

ChatTerJI Suniti Kumar. 1960. Indo-Aryan and Hindi. Calcutta: K.L Mukhopadhyay.

Chatter.s Suniti Kumar. 1970 [1926]. The Origin and Development of the Bengali Language. Delhi: Motilal Banarsidass.

Comrie Bernard. 1978. "Ergativity.” In: Lehmann 1978: 323-393.

DAs Pradeep Kumar. 2006. Grammatical Agreement in Hindi-Urdu and its Varieties. München: Lincom Europa.

Dixon Robert M.W. 1979. "Ergativity.” Language 55, 59-138.

Dixon Robert M.W. 1994. Ergativity. Cambridge: Cambridge University Press.

Dyвo Anna V., Dybo Vladimir A., Mudrak Oleg A., Starostin George S. 2006. Aspekty komparativistiki. Moskva: Rosijskij Gosudarstvennyj Gumanitarnyj Universitet (Orientalia et Classica: Trudy Instituta Vostočnych Kultur i Antičnosti: Vypusk VIII).

GondA Jan. 1951. Remarks on the Sanskrit Passive. Leiden: E.J. Brill.

GondA Jan. 1960a. "Reflections on the Indo-European medium I." Lingua 9, 30-67.

GondA Jan. 1960b. "Reflections on the Indo-European medium II." Lingua 9, 175-193.

Grierson George A. 2005 [1903-1928]. Linguistic Survey of India. Delhi: Low Price Publications.

GusAIN Lakhan. 2000. Bagri. München: Lincom Europa. Languages of the World/Materials 385.

GusAIN Lakhan. 2001. Shekhavati. München: Lincom Europa. Languages of the World/Materials 385.

GusAIN Lakhan. 2003. Mewati. München: Lincom Europa. Languages of the World/Materials 386.

GusAIN Lakhan 2004. Marwari. München: Lincom Europa. Languages of the World/Materials 427.

JuYĀL Guṇanand. 1973. Madhya pahāṝ bhāṣā (gaṛhvālī kumāũnī) kāa anuśilan aur uskā hind̄̄ se sambandh. Lakhnau: Navayug Granthāgār.

Kellog S.H. 1972 [1875]. A Grammar of the Hindi Language. New Delhi: Munshiram Manoharlal.

КнокнцоvA Ludmila V. 1974. "Sintaktičeskaja intereferencija otpričastnych konstrukcij v dialektach radžastani." Vestnik Moskovskogo Universiteta 2, 84-93.

Kнокнцоva Ludmila V. 1992. "Trends in the Development of Ergativity in New Indo-Aryan." Osmania Papers in Linguistics 18, 71-89.

Кнокнцоva Ludmila V. 1995. "The Development of Patient-Oriented Constructions in Late Western NIA Languages." Osmania Papers in Linguistics 21, 15-51.

КнокнLоva Ludmila V. 2000. "Typological Evolution of Western NIA Languages.” Berliner Indologische Studien (BIS) $13 / 14,117-142$.

Кнокнцоva Ludmila V. 2001. "Ergativity Attrition in the History of Western New Indo-Aryan languages (Punjabi, Gujarati and Rajastahani)." The Yearbook of South Asian Languages and Linguistics, 159-184.

Кнокнцоva Ludmila V. 2002. "Syntactic Peculiarities of Rajasthani", paper read at the $17^{\text {th }}$ European conference on Modern South Asian Studies, Heidelberg, September 9-14. http://www.iaas.msu.ru/pub_on/khokhlova

КнокнLоvA Ludmila V. 2006. "Sintaktičeskaja evolucija zapadnych novoindijskich jazykov v 15-20 vv.” In: Dyво et al. 2006: 151-186.

KHOKHLOva Ludmila V., SINGH Charanjit 2007. "Resultative Constructions in Western NIA languages.” In: MASICA 2007: 91-108.

KLIMOv Georgij Andreevič. 1972. "K xarakteristike jazykov aktvnogo stroja.” Voprosy Jazykoznanija 4, 3-13.

KuıMov Georgij Andreevič. 1973. Očerk obščej teorii èrgativnosti. Moskva: Izdatel'stvo 'Nauka'. 
KLIMOv Georgij Andreevič. 1976. "Voprosy kontensivno-tipologičeskogo opisanija jazykov.” In: SerebrenNikov, JARCEVA 1976: 122-146.

KuImov Georgij Andreevič. 1977. Tipologija jazykov aktivnogo stroja. Moskva: Izdatel'stvo 'Nauka'.

Kurmov Georgij Andreevič. 1983. Principy kontensivnoj tipologii. Moskva: Izdatel'stvo 'Nauka'.

LĀḶAS Padmaśri Sītārām. 1994. Rājasthānī bhāạā-sāhitya evam vyākaraṇ. Jodhpur: Ćaupāsanī Śikṣā Samiti.

LĀṭAs Padmaśri Sītārām. 1997. Rājasthānī vyākaraṇ. Jodhpur: Rājasthānī Śodh Samsthān, Ćaupāsan̄̄.

LAZARD Gilbert. 1998. Actancy. Berlin-New York: Mouton de Gruyter.

Lehmann Winfred P. (ed.). 1978. Syntactic Typology: Studies in the Phenomenology of Language. Texas: University of Texas Press.

Lehmann Winfred P. 1989. "Problems in Proto-Indo-European Grammar: Residues from Pre-Indo-European Active Structure." General Linguistics 29(4), 228-246.

LeHmann Winfred P. 1995. Residues of Pre-Indo-European Active Structure and their Implications for the Relationship among the Dialects. Innsbruck, Insbrucker Beiträge zur Sprachwissenschaft, Vorträge und Kleinere Schriften 61.

MAGIER David. 1983. Topics in the Grammar of Marwari. Berkeley (University of California PhD thesis).

Masica Colin P. 1993. The Indo-Aryan languages. Cambridge: Cambridge University Press.

MenĀRIYĀ Motīlāl. 2006. Rājasthānī bhāṣā aur sāhitya. Jodhpur: Rājasthānī granthāgār.

Montaut Annie. 2004. "Oblique Main Arguments in Hindi /Urdu as Localizing Predications.” In: Bhaskararao \& KARUMURI 2004: 33-56. http://anniemontaut.free.fr/publications.htm

Montaut Annie. 2004. A Grammar of Hindi. München: Lincom Europa.

Paṇịt B.S. 1936. "The Syntax of the Past Tense in Old Rājasthānī." Bulletin of the School of Oriental Studies $8(2 / 3), 695-698$.

PANT Prabhā. 2006. Kumāũñ̄ lok kathā. Almoṛā: Maniṣ Prakāśan.

PAYNE John R. 1980. “The Decay of Ergativity in Pamir Languages.” Lingua 51, 147-186.

Peterson John. 1998. Grammatical Relations in Ali and the Emergence of Ergativity in Indo-Aryan. München: Lincom Europa.

REGAMEY Constantin. 1954. “A propos de la 'construction ergative' en indo-aryen moderne.” In: RedARD 1954: 363-381.

Regamey Constantin. 1970. "Le problème de l'ergatif." Bulletin du Cercle Linguistique de Copenhague 19411965, VIII-XXXI, 111-112.

RuvĀLī Keśavdatt. 1983. Kumāũnī hindī vyutpattikoś. Alīgaṛh: Granthāyan Sarvodaynagar Sāsan̄̄geț.

SAKSEna Baburam. 1971 [1937]. Evolution of Awadhi. Delhi: Motilal Banarsidass.

ŠAmatov Azad N. 1974. Klassičeskij dakxini. Moskva: Izdatel'stvo 'Nauka'.

Sharma D.D. 1985. The Formation of Kumauni language. Part I: Phonology and morphophonemics. New Delhi: Bahri Publications.

Sharma D.D. 1987. The formation of Kumauni language. Part II: Morphology and syntax. New Delhi: Bahri Publications.

ŚARMĀ Kanheyālāl. 1991. Pūrvī rājasthānī: udbhav aur vikās. Jaypur: The Students Book Company.

Skalmowski Wojciech. 1974. "Transitive Verb Constructions in the Pamir and Dardic Languages." Studia Indoeuropejskie. Prace Komisji Językoznawstawa 37, 205-212 [= 2004: 89-95].

SkalmOWSKi Wojciech. 1976. "Elamite and Akkadian Translations of the Old Persian Periphrastic Perfect." Folia Orientalia 17, 217-229 [= 2004: 17-27].

Skalmowski Wojciech. 2004. Studies in Iranian Linguistics and Philology. Kraków: Wydawnictwo Uniwersytetu Jagiellońskiego.

ŚĀRDĀ Sādhurām (ed.). n.d. Hariyāṇā kī upbhāšāẽe. Caṇụ̄̄gaṛh: Nideśak, Bhāṣā Vibhāg, Hariyāṇā. (27444 Govt. Press, Chandigarh).

ŚARMĀ İśvarī Prasād. n.d. 'Mevātî̀' in Śārdā (ed.) n.d. 271-336.

Tessitori Luigi Pio. 1913. "On the Origin of the Dative and Genitive Postpositions in Gujarati and Marwari." Journal of the Royal Asiatic Society 553-567.

Tessitori Luigi Pio. 1979 [1914-1916]. Purānī rājasthānī. Translated into Hindi by Namvar Singh. New Delhi: Vānī Prakāśan ["Notes on the grammar of the Old Western Rajasthani with special reference to Apabhramsa and Gujarati and Marwari". Indian Antiquary.]

ṬHĀKUR Maulūrām. 1975. Pahāṛī bhāṣā kuluī ke viśeș sãdarbh mẽ. Dillī: Sanmārg Prakāśan.

TIKKANEn Bertil. 1988. "On Burushaski and Other Ancient Substrata in Northwest South Asia." Studia Orientalia (Helsinki) 64, 303-325. 
VARMA Siddheshvar. 1936. "The Rudhārī Dialect.” Indian Linguistics 6, 128-196.

ZakHARYIN Boris. 1979. "On the Formation of Ergativity in Indo-Aryan and Dardic." Osmania Papers in Linguistics 5, 50-71.

ZAKHARYIN Boris. 1982. "Problemy jazykovych kontaktov w indijskich Gimalajach." Vestnik Moskovskogo Universiteta. Serija 13, Vostokovedenije 3, 31-42.

Allatum die 22 mensis Octobris Anno 2010 